\title{
PREVENTION OF TADALAFIL INDUCED BACKACHE IN ERECTILE DYSFUNCTION PATIENTS
}

\author{
A. Sri Sennath Joseph Arul 1
}

${ }_{1}^{1}$ HOD, Department of Psychiatry, Karpagam Faculty of Medical Sciences and Research, Coimbatore, Tamilnadu.

\section{ABSTRACT}

Back pain is a known side effect associated with tadalafil use in erectile dysfunction patients. This is a unique and first of kind study that deals with its prevention.

\section{AIMS AND OBJECTIVES}

To prevent discontinuation of tadalafil in needy patients with erectile dysfunction due to back pain.

\section{MATERIALS AND METHODS}

Among 956 erectile dysfunction patients started on tadalafil $10 \mathrm{mg}$ daily in an outpatient clinic over 2 yrs., 79 patients discontinued due to back pain. They were restarted with tadalafil $10 \mathrm{mg}$ daily and two add-on drugs (Combination) for initial three days. The observations were noted.

\section{RESULTS}

This add-on regimen was $96.2 \%$ successful in preventing tadalafil induced backache when tadalafil was reintroduced.

\section{CONCLUSION}

Tadalafil discontinuation due to back pain can be avoided in needy erectile dysfunction patients by following this add-on regimen for just three days.

\section{KEYWORDS}

Back Pain, Tadalafil, Erectile Dysfunction.

HOW TO CITE THIS ARTICLE: Arul ASJ. Prevention of tadalafil induced backache in erectile dysfunction patients. J. Evolution Med. Dent. Sci. 2016;5(27):1410-1412, DOI: 10.14260/jemds/2016/332

\section{INTRODUCTION}

Back pain along with pain radiating to legs/myalgia on taking tadalafil is a known adverse event associated with tadalafil use. In a patient already stressed with erectile dysfunction, this side effect causes severe mental distress. According to research by Adseftel et al., all radiological and biochemical investigation performed during or after the back pain or myalgia were normal. Increased blood supply due to PDE5 (Phosphodiesterase 5) suppression was the postulated mechanism and usual onset was within $24 \mathrm{hrs}$. of taking tadalafil (12 to $24 \mathrm{hrs}$.) and back pain or myalgia were relieved within $48 \mathrm{hrs}$. (24 to $48 \mathrm{hrs}$.).[1] But in a day-to-day practice, some patients could not tolerate this back pain or myalgia and discontinued tadalafil.[2,3,4] In these patients successful reintroduction of tadalafil without this distressing back pain or myalgia with the help of two add-on drugs (Combination) was attempted in this study.

\section{METHODS}

This study was conducted over a two-year period Feb. 2014 to Jan. 2016 in a sexology outpatient clinic. Since back pain is a known side effect of tadalafil, patients with previous history of back pain were excluded from this study.

Financial or Other, Competing Interest: None.

Submission 23-02-2016, Peer Review 14-03-2016,

Acceptance 17-03-2016, Published 04-04-2016.

Corresponding Author:

Dr. A. Sri Sennath Joseph Arul,

\#4, Tower line Colony,

Kumalan Kuttai, Collectorate Post,

Erode-638011,

Tamilnadu.

E-mail: neuropsychiatrist@gmail.com

DOI: $10.14260 /$ jemds $/ 2016 / 332$
During this period among 956 patients started on tadalafil $10 \mathrm{mg}$ daily for their erectile dysfunction after baseline investigation, those who developed back pain or myalgia with tadalafil and wanted to stop the drug in spite of repeated reassurance that pain is self-limiting were segregated. They were asked to stop the drug. In this twoyear period, the total number of patients who stopped taking tadalafil due to this were 79 . All these 79 patients did not have any history of back pain before taking tadalafil. In these patients after a drug wash over a period of one week, the back pain or myalgia was completely relieved. Reintroduction of tadalafil $10 \mathrm{mg}$ daily was attempted along with 1 . Aceclofenac $100 \mathrm{mg}+$ Chlorzoxazone $250 \mathrm{mg}+$ Paracetamol $325 \mathrm{mg}$ combination and 2. Pantoprazole $40 \mathrm{mg}+$ Domperidone $10 \mathrm{mg}$ combination (In empty stomach) for the initial three days. The results were tabulated. See Table 1 and 2 and Chart 1 and 2.

\section{RESULT}

Out of 79 patients 55 were married, 12 unmarried, 7 separated and 5 divorced. They were in the age group of 24 to 35 years. Two patients (2.53\%) discontinued due to unknown reasons and one patient $(1.27 \%)$ discontinued due to gastrointestinal irritation probably induced by Aceclofenac. Among the rest 76 patients (96.2\%), none of them developed back pain or myalgia again and are on tadalafil still. See Table 3 and Chart 3.

\begin{tabular}{|c|c|c|}
\hline No. & Particulars & $\begin{array}{c}\text { Number of } \\
\text { Patients }\end{array}$ \\
\hline 1 & $\begin{array}{c}\text { Total Number of Patients on Tadalafil } \\
\text { 10 mg over a two-year period }\end{array}$ & 956 \\
\hline 2 & $\begin{array}{c}\text { Patients who Discontinued due } \\
\text { to back pain }\end{array}$ & 79 \\
\hline \multicolumn{2}{|c|}{$\begin{array}{c}\text { Table 1: Table showing the Total Patients and the } \\
\text { Patients who Discontinued due to Back Pain }\end{array}$} \\
\hline
\end{tabular}




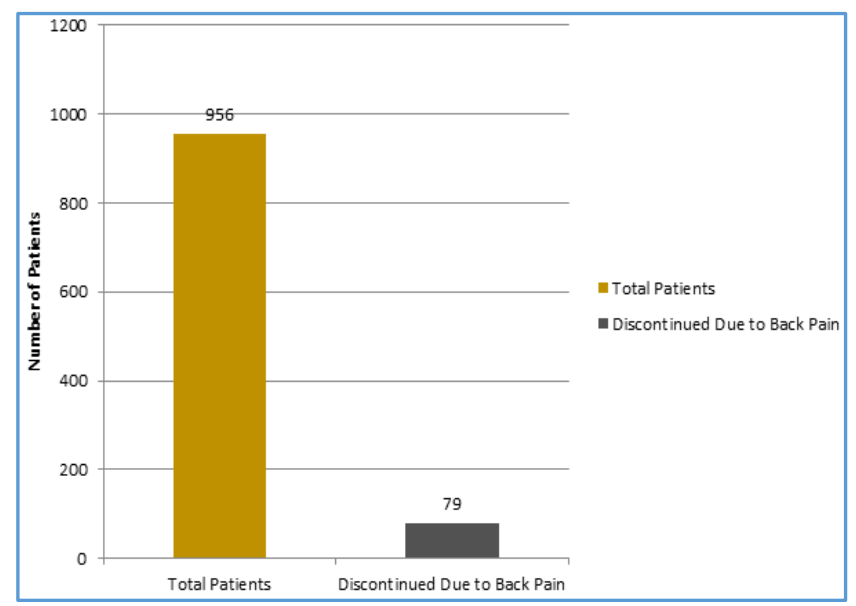

Chart 1: Chart showing the Total Patients and the Patients who Discontinued due to Back Pain

\begin{tabular}{|c|c|c|}
\hline No. & Particulars & $\begin{array}{c}\text { Number of } \\
\text { Patients }\end{array}$ \\
\hline 1 & $\begin{array}{c}\text { Patients did not } \\
\text { develop back pain }\end{array}$ & 877 \\
\hline 2 & $\begin{array}{c}\text { Discontinued due } \\
\text { to back pain }\end{array}$ & 79 \\
\hline & Total & $\mathbf{9 5 6}$ \\
\hline
\end{tabular}

Table 2: Table showing the Patients who Discontinued due to Back Pain and those who did Not Develop Back Pain

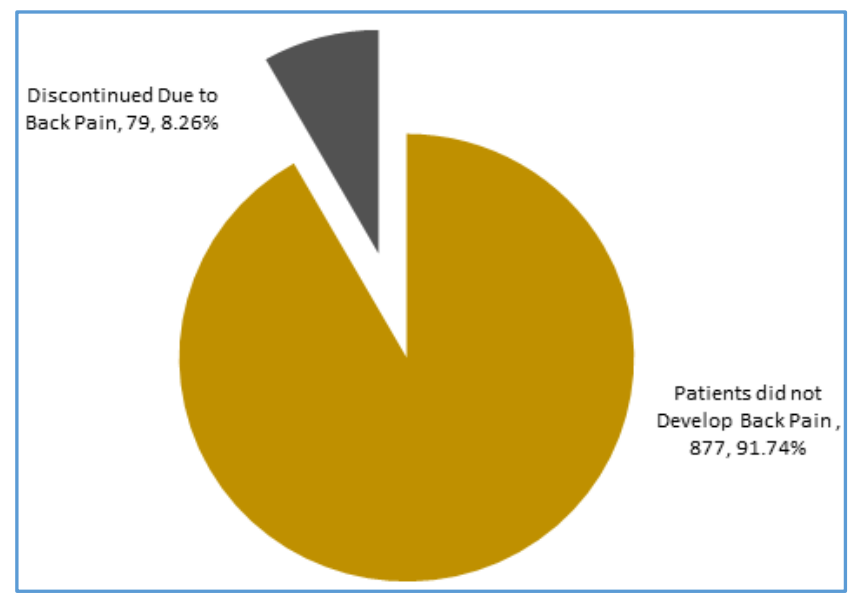

Chart 2: Chart showing the Patients who Discontinued due to Back Pain and those who did Not Develop Back Pain

\begin{tabular}{|c|c|c|c|}
\hline No. & Particulars & $\begin{array}{c}\text { Number of } \\
\text { Patients }\end{array}$ & Percentage \\
\hline 1 & $\begin{array}{c}\text { Discontinued due } \\
\text { to unknown } \\
\text { reason }\end{array}$ & 2 & 2.53 \\
\hline 2 & $\begin{array}{c}\text { Discontinued } \\
\text { due to GI distress }\end{array}$ & 1 & 1.27 \\
\hline 3 & $\begin{array}{c}\text { Patient without } \\
\text { back pain after } \\
\text { reintroduction }\end{array}$ & 76 & 96.20 \\
\hline \multicolumn{2}{|c|}{ Total } & 79 & $\mathbf{1 0 0 . 0}$ \\
\hline \multicolumn{2}{|c|}{ Table 3: Table showing Patients who Discontinued and } \\
those who Continued after Reintroduction
\end{tabular}

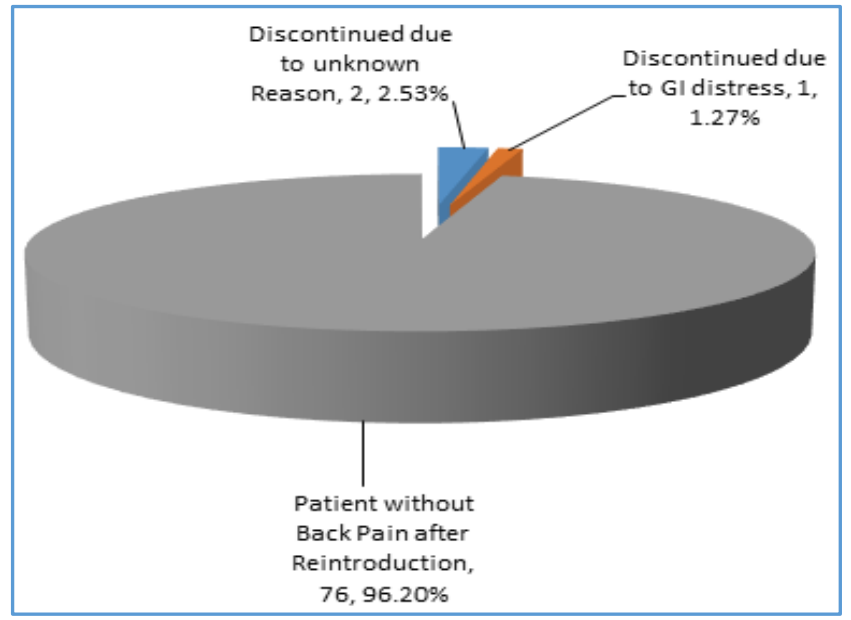

Chart 3: Chart showing those Patients who Discontinued and those who Continued after Reintroduction

\section{DISCUSSION}

In a male potency is a synonym for masculinity. Patients who have erectile dysfunction, particularly in Indian setup are further confused by lots of myths and misconceptions about sex. This adds on to their problem. In this scenario when they develop back pain or myalgia with tadalafil, it definitely increase their emotional distress further.[2,5] In spite of repeated reassurances and explanation that this pain is selflimiting (Adseftel et al.), their fear is difficult to alleviate.[1] So they were allowed to discontinue the drug with an explanation that symptoms are due to increased blood supply (Adseftel et al.) and it will stop once the drug is discontinued. $[6,7,8]$

They were then individually explained the benefits of tadalafil versus side effects and reassured that restarting tadalafil along with the two add-on drugs Aceclofenac $100 \mathrm{mg}$ + Chlorzoxazone $250 \mathrm{mg}+$ Paracetamol $325 \mathrm{mg}$ combination and 2. Pantoprazole $40 \mathrm{mg}+$ Domperidone $10 \mathrm{mg}$ will prevent back pain or myalgia. Research by Samuel et al. put the discontinuation rate due to side effects of tadalafil was between $1 \%$ to $6 \% .{ }^{[5,9]}$ Research by Carson et al. showed that $11 \%$ of patients developed back pain with $10 \mathrm{mg}$ of tadalafil.[3] Other research by Carson et al. and Montorsi et al. put discontinuation rate due to total adverse events as $3.2 \%$ and $6.4 \%$ respectively.[3,4]

The relative high affinity of tadalafil for phosphodiesterase 11, an isoform found in skeletal muscle is considered to be related to the higher incidence of back pain or myalgia in patients on tadalafil according to research by Samuel Washington et al.[5] Though research say this back pain is self-limiting, Adseftel et al.[1,8] Psychiatrists, sexologists and urologists must definitely pay attention to the emotional distress associated with back pain, particularly when it develops in a patient already suffering from erectile dysfunction. This is much more important in an Indian scenario filled with myths and misconceptions about sex, which further complicates the problem.

\section{CONCLUSION}

This study concludes that discontinuation rates due to back pain associated with tadalafil use in erectile dysfunction is high in Indian population and this causes further distress to the patient. By adding a simple regimen of these two drugs 
for only three days, the patient will be able to avoid back pain and also improve his erection, thereby retaining the marital bliss.

\section{REFERENCES}

1. Seftel AD, Deeley MC, Fletcher J, et al. A three part study to investigate the incidence and potential aetiologies of tadalafial associated back pain or myalgia. International journal of impotence research 2005;17(5):455-61.

2. Brock GB, McMahon CG, Chen KK, et al. Efficacy and safety of tadalafil for the treatment of erectile dysfunction: results of integrated analysis. J urol 2002;168(2):1332-6.

3. Montorsi F, Verheyden B, Meuleman E, et al. Long term safety and tolerability of tadalafil in the treatment of erectile dysfunction. Eur Urol 2004;45(3):339-345.

4. Carson C, Shabsigh R, Segal S, et al. Efficacy, safety and treatment satisfaction of tadalafil versus placebo in patients with erectile dysfunction evaluated at tertiary care academic centres. J urol 2005;65(2):353-9.
5. Wahington SL $3^{\text {rd }}$, Shindel AW. A once daily dose of tadalafil for erectile dysfunction: compliance and efficacy. Drug Des Devel Ther 2010;4:159-171.

6. McMahon C. Efficacy and safety of daily tadalafil in men with erectile dysfunction previously unresponsive to on demand tadalafil. J Sex med 2004;1(3):292-300.

7. Porst H, Giuliano F, Glina S, et al. Evaluation of the efficacy and safety of once a day dosing of tadalafil $5 \mathrm{mg}$ and $10 \mathrm{mg}$ in the treatment of erectile dysfunction: results of a multicenter, randomized, double-blind, placebo-controlled trial. Eur Uro 2006;50(2):351-359.

8. Seftal AD, Buvat J, Althof F, et al. Improvement in confidence, sexual relationship and satisfaction measures: results of a randomized trial of tadalafil $5 \mathrm{mg}$ taken once daily. Int J impot Res 2009;21(4):240-248.

9. Donatucci CF, Wong DG, Giuliano F, et al. Efficacy and safety of tadalafil once daity: considerations for the practical application-of a daily dosing option. Curr Med Res Opin 2008;24(12):3383-3392. 